\title{
Diet of the lizard Liolaemus occipitalis in the coastal sand dunes of southern Brazil (Squamata-Liolaemidae)
}

\author{
Verrastro, L. ${ }^{a *}$ and Ely, I. ${ }^{a}$ \\ aPrograma de Pós-Graduação em Biologia Animal, Departamento de Zoologia, Instituto de Biociências, \\ Universidade Federal do Rio Grande do Sul - UFRGS, Av. Bento Gonçalves, 9500, prédio 43435, \\ Bairro Agronômia, CEP 91501-970, Porto Alegre, RS, Brazil \\ *e-mail: lauraver@ufrgs.br
}

Received: July 4, 2013 - Accepted: December 5, 2013 - Distributed: May 31, 2015

(With 1 figure)

\begin{abstract}
Knowledge of a species' diet provides important information on adaptation and the relationship between the organism and its environment. The genus Liolaemus occurs in the southern region of South America and is an excellent model to investigate the adaptive processes of vertebrate ecology in ecosystems of this region of the world. Liolaemus occipitalis is an endangered species that inhabits the coastal sand dunes of southern Brazil. This species is the most abundant vertebrate in this environment, and it presents unique adaptation characteristics to the restinga environment. The present study analyzed this lizard's diet to verify similarities or differences between this species and other species of the same genus. Specimens were collected monthly from January 1996 to December 1997. The number of items, frequency of occurrence and volume of each prey taxon were determined. Arthropods were identified to the order level, and plant material was identified as flower, fruit, seed and leaves. Variations in the diet of males and females, adults and juveniles and seasons were also analyzed. The data indicate that Liolaemus occipitalis is a generalist, "sit-and-wait" or ambush predator as well as omnivorous, feeding on both arthropods and plant material. Significant ontogenetic differences were verified. Juveniles are more carnivorous, and the intake of plant material increases with size and age. Seasonal differences in diet composition were also observed. In the spring, arthropod and plant materials were more diversified and, therefore, consumed more often.
\end{abstract}

Keywords: Liolaemus, southern Brazil, restinga, foraging, seasonal variation.

\section{Dieta do lagarto Liolaemus occipitalis nas dunas costerias do sul do Brasil (Squamata-Liolaemidae)}

\section{Resumo}

O conhecimento sobre a dieta de uma espécie traz informações importantes sobre a adaptação e relações entre o organismo e seu ambiente. O gênero Liolaemus, que ocorre na região austral da América do Sul, tem-se mostrado como excelente modelo em ecologia de vetebrados para entender os processos adaptativos nos ecossistemas desta região do mundo. Liolaemus occipitalis é uma espécie ameaçada de extinção que habita as dunas costeiras do extremo sul do Brasil. É o vertebrado mais abundante neste ambiente e apresenta características peculiares de adaptação aos ambientes de restingas. No presente estudo analisou-se a dieta deste lagarto com o intuito de verificar se há diferenças com as espécies do gênero ou segue o mesmo padrão. Foram realizadas coletas mensais entre janeiro/96 e dezembro/97. Determinou-se o número de itens, a frequência de ocorrência e o volume de cada táxon de presa, identificados até o nível de ordem, no caso dos artrópodes, e como flor, fruto, semente e folhas o material vegetal. Foram analisadas as variações da dieta entre machos e fêmeas, entre adultos e jovens, e também entre as estações. Os dados indicam que Liolaemus occipitalis possui uma dieta onívora consumindo tanto artrópodes como material vegetal. Caracteriza-se por ser um predador generalista, forrageando de modo "senta-e-espera". Determinaram-se diferenças significativas entre a dieta de jovens e adultos. Entre as variações ontogenéticas, constatou-se que lagartos jovens apresentam um hábito mais carnívoro, e a inclusão do material vegetal na dieta aumenta sucessivamente com o tamanho/idade do animal. Verificaram-se diferenças na composição da dieta ao longo das estações, sendo mais diversa na primavera em relação ao consumo de artrópodes, e com maior consumo de material vegetal.

Palavras-chave: Liolaemus, sul do Brasil, restinga, forrageio, sazonalidade. 


\section{Introduction}

The trophic relationship between lizards and their environment and the foraging strategies for obtaining food resources are important aspects of the ecology of these organisms (Pianka, 1982; Silva and Araújo, 2008). Foraging is related to different aspects of a lizard's life history, such as reproductive cycle, seasonal patterns, population dynamics, growth patterns (Vitt, 1990) and predator escape mechanisms (Huey and Pianka, 1981; Magnusson et al., 1985; Vitt, 1990).

Lizards may have two basic foraging strategies: "sitand-wait" or sedentary ambush foraging and active or wide-ranging foraging. Lizard species are found along a continuum between these two extremes (Huey and Pianka, 1981; Cooper, 1995; Stephen et al., 2007). One of the primary outcomes of the different foraging patterns of diurnal lizards is the diversity and abundance of the consumed prey, which results from the range of the foraging territory.

The diet composition of a lizard species may vary between sexes, seasonally or ontogenetically. The diet of males and females of some species differs quantitatively and qualitatively to reduce intersexual competition (Schoener, 1967) or because of morphological differences, especially head and jaw size (Fitch, 1978). Seasonal variations in diet are usually associated with the availability of prey in the environment. This variation was verified in Cnemidophorus tigris BAIRD and GIRARD, 1852 (Pianka, 1970), Polychrus acustirostris SPIX, 1825 (Vitt and Lacher, 1981), Iguana iguana (LINNAEUS, 1758) (Schoener et al., 1982), Plica plica (LINNAEUS, 1758) (Vitt, 1991), Tropidurus itambere (RODRIGUES, 1987) (Van Sluys, 1995), Mabuya macrorhyncha (HOGE, 1946) (Vrcibradic and Rocha, 1995), Liolaemus lutzae (MERTENS, 1938) (Rocha, 1996), Tropiduru torquatus (WIED-NEUWIED, 1820) (Fialho et al., 2000) and $C$. littoralis (ROCHA, ARAÚJO, VRCIBRADIC and COSTA, 2000) (Teixeira-Filho et al., 2003). Ontogenetic variations may appear in the size or type of prey. Juveniles of many species are essentially carnivorous and feed on larger quantities of smaller prey, whereas adults are omnivorous or herbivorous and feed on smaller quantities of larger prey (Schoener and Gorman, 1968; Ortiz, 1974; Ortiz and Riveros, 1976; Stamps et al., 1981; Rocha, 1989; Magnusson and Silva, 1993; Fialho et al., 2000).

The austral herpetofauna of South America exhibits significant diversity and richness of lizard species of the Liolaemini clade, which includes the genus Liolaemus WIEGMANN, 1834 (approx. 225 species according to Ávila et al., 2010). Lizards of this genus exhibit ecological variability that is independent of their phylogenetic relationships, which makes these lizards excellent models for vertebrate ecological studies (Espinoza et al., 2004; Tulli et al., 2011). Several studies on the diet of this genus have been published (Ortiz and Riveros, 1976; Fuentes and Ipinza, 1979; Jaksic and Fuentes, 1980; Rocha, 1989; Ávila and Acosta, 1993; Vega, 1999; Belver and Avila, 2001; Halloy et al., 2006; Azócar and Acosta,
2011). Liolaemus ssp. are excellent representatives of the pattern observed in species of the Iguana group within the foraging models of lizards (Huey and Pianka, 1981). The genus Liolaemus encompasses insectivorous, omnivorous and herbivorous species (Etheridge and Espinoza, 2000; Espinoza et al., 2004). Carnivorous and omnivorous Liolaemus lizards are ambush foragers and present features of the sit-and-wait model for Squamata, such as the prevalence of mobile prey and relatively diverse diets. Most lizards of this genus present ontogenetic variation throughout their lifespan. Omnivorous Liolaemus species increase their intake of plant material in the adult stage. Several smaller species than those considered by Pough (1973) show an evident tendency to herbivory (Jaksic, 1978; Greene, 1982; Rocha, 1992; Van Sluys, 1993; Espinoza et al., 2004). The genus Liolaemus also shows the same tendency, including L. pictus pictus (DUMÉRIL and BIBRON, 1837) (Ortiz, 1974), L. nigromaculatus kulhmani MÜLLER and HELLMICH, 1933 (Jaksic, 1978) and L. lutzae (Rocha, 1989; 1992). However, Espinoza et al. (2004) stated that different herbivory levels in the genus Liolaemus have appeared during evolution as adaptations to cold environments. Therefore, the Liolaemus species are part of a group of small omnivorous and/or herbivorous tropidurid lizards that occur in the southern extreme of South America (Vitt and Caldwell, 2009).

Brazil contains three species of the genus Liolaemus: Liolaemus lutzae MERTENS, 1938; L. occipitalis BOULENGER, 1885 and L. arambarensis VERRASTRO et al., 2003. L. occipitalis is a small sand lizard that is found in the coastal sand dune environment in the southern extreme of Brazil (sandbank vegetation, or restinga, habitat) in the states of Rio Grande do Sul (RS) and Santa Catarina (SC) (Peters et al., 1986; Lema, 1994; Verrastro, 2004). These lizards are also found on the east coast of Uruguay (Verrastro et al., 2006). This lizard, which reaches a maximum size of $60 \mathrm{~mm}$, is oviparous and active during the day between 10 a.m. and 4 p.m., and its reproductive period lasts from September to March (Verrastro and Bujes, 1998; Verrastro and Krause, 1999). The lizards are associated with clumps of herbaceous vegetation spread throughout the mobile sand dunes where the lizards find food resources, shelter from predators and thermoregulation sites (Verrastro and Bujes, 1998; Bujes and Verrastro, 2006). These lizards bury themselves in the soft sand and may build burrows in the harder sand to seek refuge during the hottest hours of the day or during winter (Bujes and Verrastro, 2006; Bujes and Verrastro, 2008).

Liolaemus occipitalis was included in the Lista Nacional das Espécies Ameaçadas de Extinção (Brazilian's list of endangered species) by the official document entitled Instrução Normativa $n^{\circ} 003$, de 26 de maio de 2003, and it remains on this list (ICMBio-MMA, 2013). The state of RS reviewed its list of endangered species in 2013 and categorized L. occipitalis as Vulnerable (VU) due to threats to its habitat and a severe reduction in its home range (http://www.liv.fzb.rs.gov.br/livcpl/?id_modulo=1\&id_uf=23). 
Knowledge of natural history is important to better establish conservation criteria for this species and its environment.

We sought to describe the diet of a population of Liolaemus occipitalis in the sand dunes of the municipality of Cidreira, state of RS, to verify whether this species follows the patterns within the genus.

This study investigated the composition of this species' diet, foraging behavior, ontogenetic and intersexual variations in the diet composition and seasonal variations in diet.

\section{Material and Methods}

This study was performed in the municipality of Cidreira ( $30^{\circ} 17^{\prime} 07^{\prime \prime} \mathrm{S}$ and $50^{\circ} 11^{\prime} 05^{\prime} \mathrm{W}$ ) on the RS 786 highway, which connects the municipalities of Tramandaí and Cidreira in the State of RS, Brazil. The study was performed between January 1996 and December 1997, except for a period between June and August 1996, when the access to the area was prevented by rainfall. The area is characterized by the presence of mobile sand dunes and mostly sandy soil, and herbaceous vegetation covers 10 to $15 \%$ of the terrain (Waechter, 1990; Dillenburg et al., 1992). The climate is subtemperate according to Maluf's classification (Maluf, 2000). The mean annual rainfall is $1323 \mathrm{~mm}$ with no typical dry season and a mean annual temperature of $20^{\circ} \mathrm{C}$ (Hasenack and Ferraro, 1989).

Individuals were collected manually once a month between 10:30 a.m. and 2:30 p.m. Specimens were weighed in the field on a set of $0.1 \mathrm{~g}$ precision scales and sacrificed with Citanest (3\%) immediately afterwards. The specimens were fixed in $10 \%$ formalin for $72 \mathrm{~h}$, preserved in $70 \%$ ethanol and vouchered in the Collection of Amphibians and Reptiles of the Department of Zoology of the Universidade Federal do Rio Grande do Sul (UFRGS). The biometric measurements of snout-vent length (SVL) and jaw width (JW) were taken in the laboratory using a caliper with $0.1 \mathrm{~mm}$ precision. Sex was identified by the presence or absence of cloacal pores and color according to Verrastro (2004). Males were considered adults if the SVL was at least $50.0 \mathrm{~mm}$, and females were considered adults if the SVL was at least $45.0 \mathrm{~mm}$ (Verrastro and Krause, 1994).

The lizards were dissected, and their stomach contents were analyzed under a stereomicroscope to identify, quantify and measure the food items. Arthropods were identified to the Order level with the additional separation of Hymenoptera into two categories, "Formicidae" and "Others". Coleoptera and Lepidoptera were also classified into two categories, "Adults" and "Larvae". All plant material was grouped together and subdivided into flowers, fruits, seeds, fibers and leaves.

The diet of $L$. occipitalis was analyzed quantitatively and qualitatively. The diet was compared using the Kolmogorov-Smirnov test to determine whether the data from the two years should be analyzed together or separately (Siegel, 1975). The qualitative analysis considered only the presence of each food item in the diet composition.
Non-parametric tests were used because the data were not normally distributed.

The presence of each food item (prey) determined the diet composition in the qualitative analysis. The diet composition of males and females and of adults and juveniles was analyzed separately. The number of stomachs (individuals) that contained each prey was recorded, and the data were compared using the Kolmogorov-Smirnov test (Siegel, 1975).

The quantitative analysis considered the number of consumed items in each prey taxon that was present in the stomachs. The frequency of occurrence was estimated as the number of stomachs in which a given prey item was found with respect to the total number of stomachs (individuals). Volume was estimated by measuring each item present in the stomach and applying the ellipsoid (spheroid) formula proposed by Mayhew (1963): $\mathrm{V}=4 / 3 \pi \mathrm{ab}^{2}$, where " $\mathrm{a}$ " is $1 / 2$ of the larger length of the prey and " $b$ " is $1 / 2$ of the smaller larger. The volume percentages of each prey and the number of items consumed by each individual were also calculated. Plant material was analyzed only in terms of volume and frequency of occurrence. The volume of sand was ignored in these calculations.

Ontogenetic variations were based on the two classes of body size between adults and juveniles and compared with respect to the number and volume of the consumed items using the Mann-Whitney test. The mean volume of the five larger items and the number of items consumed with respect to the SVL of a given lizard were tested using linear regression to compare differences in prey consumption between adults and juveniles and its relationship with the SVL of each individual. The size of the largest prey consumed and the lizard's JW were similarly compared. A linear regression analyzed the consumption of plant material and the SVL to assess differences in the consumption of plant material between age classes. The effect of the lizard's size on the proportion of plant material in the stomach was calculated using a regression analysis. The proportion of plant material was transformed in an arcsine square root prior to this analysis (Zar, 1984; Van Sluys, 1993; Rocha, 1996; Fialho et al., 2000).

Seasonal variations in the diet were analyzed in groups (autumn = March, April and May; winter $=$ June, July and August; spring = September, October and November; summer $=$ December, January and February). Simpson's Diversity Index compared the diversity of arthropods that were consumed by the population during the four seasons. Bootstrapping tested the differences in diversity among the seasons (Krebs, 1999; Magurran and McGill, 2011).

\section{Results}

A total of 285 individuals were collected in the restingas in Cidreira. A total of 114 individuals were collected in 1996, and 171 were collected in 1997. The sample included 135 males, 108 females and 42 juveniles. Only one empty stomach was recorded. 
Because the diet composition between 1996 and 1997 was not significantly different, the data from both years were analyzed together $(D=0.2857 ; p=0.541)$.

A total of 16 food items were identified in the diet of L. occipitalis (Table 1), which consisted of both plant and animal items. The most frequent items were Formicidae (79.65\%), Coleoptera adults (69.12\%), Thysanoptera (28.07\%) and Araneae (25.26\%). Plant material was found in $28.07 \%$ of the stomachs (Table 1). The following categories of plant material were found: flowers (19.3\%), fibers $(7.02 \%)$, seeds $(1.75 \%)$, fruits $(1.05 \%)$ and leaves $(0.35 \%)$ (Table 1$)$. The food items with the largest total volume were Coleoptera adults (15.76\%), followed by Formicidae (9.52\%) and Coleoptera larvae (5.54\%). Plant material corresponded to $7.32 \%$ of the ingested items (Table 1). Sand was found in $100 \%$ of the stomachs.

The diet composition changed throughout life, and significant differences were observed between the food items consumed by adults and juveniles $(\mathrm{D}=0.4667$; $\mathrm{p}<0.05$ ). Juvenile stomachs contained more Diptera, Coleoptera and Hemiptera adults and larvae; in contrast, plant material, Orthoptera and Lepidoptera were more frequently observed in the adult stomachs (Table 2; Figure 1). No significant differences in the number of items consumed by adults and juveniles were observed $(\mathrm{U}=6969 ; \mathrm{p}=0.2178)$, but a marginally significant correlation between the number of consumed items and lizard size was noted $\left(r^{2}=0.1211 ; p=0.068\right)$. However, it was evident that adults consumed larger prey $(U=5093$; $\mathrm{p}<0.0001)$. This difference was also observed in the relationship between the mean of the five largest items and $\operatorname{SVL}\left(\mathrm{r}^{2}=0.3706, \mathrm{p}<0.0001 ; \mathrm{N}=164\right)$ and the size of the largest prey and JW $\left(\mathrm{r}^{2}=0.3589 ; \mathrm{p}<0.0001 ; \mathrm{N}=113\right)$. Plant material was found in approximately $35 \%$ of the adult stomachs, and plant material was the most important item in the juvenile stomachs. However, only one item was

Table 1. Number of items (No.), frequency per taxon (\%), frequency of occurrence in the stomach contents (Freq), volume $\left(\mathrm{mm}^{3}\right)$ and volume percentage (Vol\%) consumed per taxon by L. occipitalis in the sandbank vegetation at Cidreira (Brazil, $\mathrm{RS})$ in $1996(\mathrm{~N}=114)$ and $1997(\mathrm{~N}=171)$.

\begin{tabular}{|c|c|c|c|c|c|}
\hline Item & No & $\%$ & Freq & Vol & Vol \% \\
\hline $\begin{array}{l}\text { 1. Hymenoptera - } \\
\text { Formicidae }\end{array}$ & 2661 & 68.80 & 79.65 & $4,217.58$ & 9.52 \\
\hline $\begin{array}{l}\text { 2. Hymenoptera - } \\
\text { others }\end{array}$ & 3 & 0.08 & 4.21 & 22.41 & 0.05 \\
\hline $\begin{array}{l}\text { 3. Coleoptera - } \\
\text { Adultus }\end{array}$ & 604 & 15.62 & 69.12 & $6,979.18$ & 15.76 \\
\hline $\begin{array}{l}\text { 4. Coleoptera - } \\
\text { Larvae }\end{array}$ & 138 & 3.57 & 10.18 & $2,452.77$ & 5.54 \\
\hline 5. Diptera & 36 & 0.93 & 9.12 & 445.89 & 1.01 \\
\hline 6. Isoptera & 1 & 0.03 & 0.35 & 5.64 & 0.01 \\
\hline 7. Homoptera & 6 & 0.16 & 1.40 & 308.20 & 0.70 \\
\hline 8. Hemiptera & 145 & 3.75 & 20.35 & $1,617.73$ & 3.65 \\
\hline 9. Orthoptera & 110 & 2.84 & 16.49 & $2,280.87$ & 5.15 \\
\hline 10. Neuroptera & 5 & 0.13 & 1.75 & 85.61 & 0.19 \\
\hline $\begin{array}{l}11 . \\
\text { Ephemeroptera }\end{array}$ & 6 & 0.16 & 2.11 & 277.02 & 0.63 \\
\hline 12. Araneae & 100 & 2.59 & 25.26 & $1,183.29$ & 2.67 \\
\hline 13. Thysanoptera & 7 & 0.18 & 28.07 & 11.22 & 0.03 \\
\hline $\begin{array}{l}\text { 14. Lepidoptera - } \\
\text { Adults }\end{array}$ & 36 & 0.93 & 10.18 & $1,499.24$ & 3.38 \\
\hline $\begin{array}{l}\text { 15. Lepidoptera - } \\
\text { Larvae }\end{array}$ & 10 & 0.26 & 3.51 & 938.50 & 2.12 \\
\hline $\begin{array}{l}\text { 16. Vegetal } \\
\text { matter }\end{array}$ & - & - & 28.07 & $3,241.50$ & 7.32 \\
\hline Flower & - & - & 19.30 & - & - \\
\hline Fruit & - & - & 1.05 & - & - \\
\hline Fiber & - & - & 7.02 & - & - \\
\hline Seed & - & - & 1.75 & - & - \\
\hline Leaves & - & - & 0.35 & - & - \\
\hline Sand & & & & $18,608.76$ & 42.01 \\
\hline Overall & 3,868 & & & $44,175.41$ & \\
\hline $\mathrm{N}^{\circ}$ stomachs & & & 285 & & \\
\hline
\end{tabular}


Table 2. Number of items (No.), frequency of occurrence in the stomach contents (Freq) and volume percentage (Vol\%) consumed by adults and juveniles $(\mathrm{D}=0.4667, \mathrm{p}=0.05, \mathrm{~N}=285)$ and by males and females $(\mathrm{D}=0.2 ; \mathrm{p}=0.889 ; \mathrm{N}=242)$ of L. occipitalis in the sandbank vegetation at Cidreira (RS, Brazil).

\begin{tabular}{|c|c|c|c|c|c|c|c|c|c|c|c|c|}
\hline \multirow[b]{2}{*}{ Item } & \multicolumn{3}{|c|}{ Adult } & \multicolumn{3}{|c|}{ Juvenile } & \multicolumn{3}{|c|}{ Male } & \multicolumn{3}{|c|}{ Female } \\
\hline & $\mathbf{N}^{0}$ & Freq & $\begin{array}{l}\text { Vol } \\
\% \\
\end{array}$ & $\mathbf{N}^{0}$ & Freq & $\begin{array}{l}\text { Vol } \\
\% \\
\end{array}$ & $\mathbf{N}^{0}$ & Freq & Vol \% & $\mathbf{N}^{0}$ & Freq & Vol \% \\
\hline 1. Araneae & 90 & 27.1 & 5.04 & 10 & 22 & 3.33 & 46 & 26.1 & 5.09 & 48 & 28.7 & 4.07 \\
\hline 2. Coleoptera & 580 & 74.6 & 30.45 & 28 & 80.5 & 6.37 & 312 & 69.4 & 25.46 & 260 & 51.9 & 31.24 \\
\hline $\begin{array}{l}\text { 3. Larvas de } \\
\text { Coleoptera }\end{array}$ & 130 & 13.1 & 9.19 & 9 & 17.1 & 23.42 & 50 & 17.2 & 10.06 & 82 & 8.33 & 7.58 \\
\hline 4. Diptera & 24 & 8.61 & 1.8 & 13 & 17.1 & 4.46 & 11 & 6.72 & 1.01 & 17 & 6.48 & 2.82 \\
\hline 5. Ephemeroptera & 5 & 2.05 & 1.04 & 1 & 2.44 & 2.6 & 4 & 2.99 & 1.49 & 1 & 0.93 & 0.26 \\
\hline 6. Hemiptera & 135 & 21.3 & 6.98 & 12 & 24.4 & 2.58 & 47 & 23.1 & 8.69 & 64 & 18.5 & 3.59 \\
\hline 7. Homoptera & 4 & 1.64 & 1.34 & 2 & 4.88 & 0.36 & 4 & 1.49 & 2.17 & 2 & 9.26 & 0.06 \\
\hline $\begin{array}{l}\text { 8. Hymenoptera } \\
\text { - Formicidae }\end{array}$ & $2,528.00$ & 83.6 & 18.07 & 160 & 75.6 & 17.18 & 1,214 & 79.9 & 15.44 & 1,219 & 84.3 & 18.95 \\
\hline $\begin{array}{l}\text { 9. Hymenoptera } \\
\text { - other }\end{array}$ & 0.00 & 0.00 & 0.00 & 3 & 7.32 & 0.00 & 1 & 0.75 & 0.13 & 2 & 1.85 & 0.04 \\
\hline 10. Isoptera & 1 & 0.41 & 0.02 & 0 & 0 & 0 & 1 & 0.75 & 0.04 & 0 & 0 & 0 \\
\hline 11. Lepidoptera & 33 & 11.9 & 6.26 & 3 & 2.44 & 5.26 & 20 & 11.9 & 7.38 & 13 & 12 & 3.6 \\
\hline $\begin{array}{l}\text { 12. Larvas de } \\
\text { Lepidoptera }\end{array}$ & 10 & 4.1 & 4.16 & 0 & 0 & 0 & 7 & 5.22 & 3.54 & 3 & 2.78 & 4.16 \\
\hline 13. Neuroptera & 4 & 2.46 & 0.36 & 1 & 2.44 & 0.32 & 2 & 1.49 & 0.38 & 4 & 3.7 & 0.32 \\
\hline 14. Orthoptera & 106 & 17.2 & 10 & 8 & 7.32 & 1.36 & 65 & 19.4 & 6.87 & 66 & 10.2 & 12.18 \\
\hline $\begin{array}{l}15 . \\
\text { Thysanoptera }\end{array}$ & 7 & 2.46 & 0.05 & 0.00 & 0.00 & 0.00 & 5 & 2.99 & 0.06 & 2 & 1.85 & 0.02 \\
\hline 16. Vegetal & - & 33.6 & 11.88 & - & 17.1 & 34.79 & - & 33.6 & 12.32 & - & 34.3 & 10.83 \\
\hline Flower & & 68.8 & & & 42.9 & & & & & & & \\
\hline Fruit & & 4.68 & & & 0 & & & & & & & \\
\hline Fiber & & 17.2 & & & 42.9 & & & & & & & \\
\hline Seed & & 7.81 & & & 14.3 & & & & & & & \\
\hline Leaves & & 1.56 & & & 0 & & & & & & & \\
\hline $\mathrm{N}^{0}$ stomachs & & 244 & & & 41 & & & 134 & & & 108 & \\
\hline Overall & 3,602 & & & 247 & & & $1,788.00$ & & & $1,781.00$ & & \\
\hline
\end{tabular}

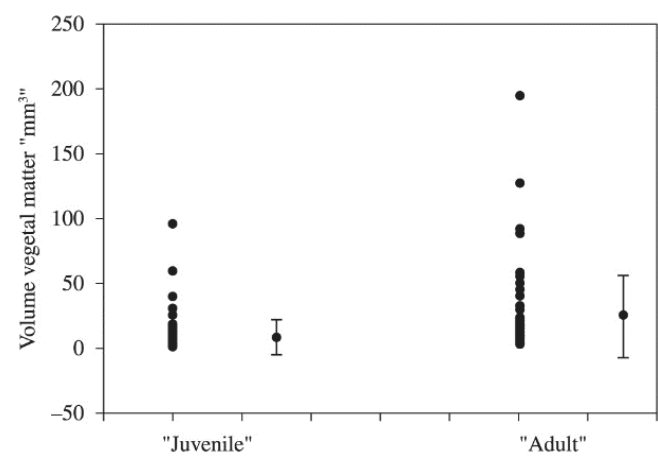

Figure 1. Percentage of plant material consumed by juveniles and adults of L. occipitalis in 1996 and 1997. The horizontal point and the vertical lines to the right represent the mean and standard deviation, respectively, for each group according to the scatter plot shown on the right $(\mathrm{N}=96$ juveniles and $\mathrm{N}=69$ adults, values expressed after arcsine square root transformation). Significant differences in the consumption of plant material were observed between juveniles and adults (Mann-Whitney Test $=U^{\prime}=5093.0 ; p<0.0001$ ). found in the stomach of a single juvenile. Adults consumed larger portions of flowers, leaves and fruits (Table 2), and juveniles consumed larger portions of seeds and fibers (Table 2). The consumption of plant material was observed in lizards with a minimum SVL of $30 \mathrm{~mm}$ and a minimum mass of approximately $0.8 \mathrm{~g}$. The proportion of total plant material volume in the lizard stomachs exhibited a highly significant and positive correlation with size $\left(r^{2}=0.9987\right.$; $\mathrm{p}<0.00001 ; \mathrm{N}=74)$.

No significant differences were observed between the diets of males and females $\left(\mathrm{D}_{\max }=0.2, \mathrm{p}=0.889\right)$, but some subtle differences were observed. Males more frequently consumed Coleoptera larvae and Hemiptera (Table 2).

Nematode parasites (Nematoda) were found in 49 stomachs $(17.19 \%)$ of L. occipitalis (34 adults and 15 juveniles). The infected individuals had an average of 3.6 worms per stomach.

The diet of $L$. occipitalis was composed of basically the same categories of food items in all study periods, but some items were not found in all seasons. Homoptera 


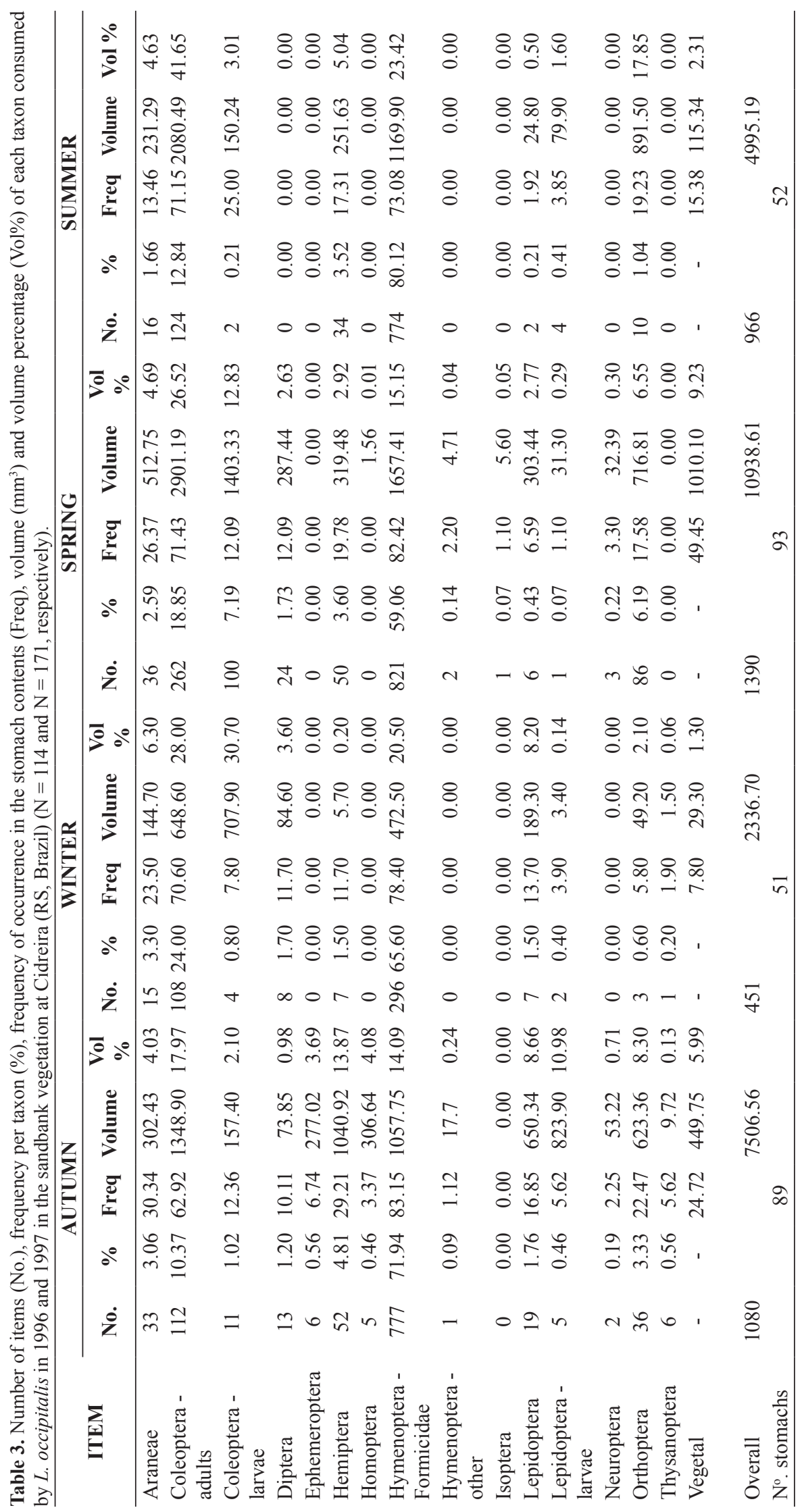


Table 4. Simpson's Diversity Index of the diet of L. occipitalis in the different seasons in the population of Cidreira/RS. The "p" values reflect significant differences between the seasons.

\begin{tabular}{lcccc}
\hline & autumn & winter & spring & summer \\
\hline autumn & 0.4636 & & & \\
winter & $\mathrm{p}=0.153$ & 0.5099 & & \\
spring & $\mathrm{p}=0.001$ & $\mathrm{p}=0.001$ & 0.6041 & 0.3779 \\
summer & $\mathrm{p}=0.003$ & $\mathrm{p}=0.001$ & $\mathrm{p}=0.001$ & \\
\hline
\end{tabular}

were found only in autumn, Neuroptera were not found in summer and winter, and Thysanoptera were not found in the spring and summer. Plant material was more frequently consumed in the spring, and Lepidoptera were more frequently consumed in the autumn and winter. Diptera were consumed more frequently in the summer (Table 3 ). The diversity of consumed items was greatest in the spring and lowest in the summer (Table 4). Significant differences in the diversity of the consumed items were observed among all seasons except winter and autumn (Table 4).

\section{Discussion}

L. occipitalis is an omnivorous species that feeds on at least 16 food items, including arthropods and plant material. This lizard's diet is similar to many species of the same genus, which encompasses carnivorous, omnivorous and exclusively herbivorous species (Espinoza et al., 2004; Acosta et al., 1996; Rocha, 1996). L. occipitalis exhibits a foraging behavior that is closer to the sit-and-wait or ambush predator mode in the foraging continuum model proposed MacArthur and Pianka (1966), Schoener (1971) and Huey and Pianka (1981). The predominance of winged and mobile prey in the diet suggests that this species, similar to most Iguanid lizards, moves infrequently while searching for food, usually consumes more active prey and has a relatively diversified diet (Huey and Pianka, 1981; Vitt and Carvalho, 1995). This categorization is corroborated by the territoriality of this species, which means that individuals tend to move very little during the day and throughout their life (Verrastro, 2001). The ambush predator strategy is associated with generalist species, which likely include L. occipitalis. The great diversity of prey confirms this association (Schoener, 1971; Vitt and Carvalho, 1995). A high frequency of ants was also observed in the stomach, and ants were the most frequently identified food item. Ants are associated with the diet of sit-and-wait foragers, but termites are associated with widely active foragers (Huey and Pianka, 1981; Magnusson et al., 1985; Vitt et al., 2003; Silva and Araújo, 2008). The high mobility and local abundance of ants favors encounters between these insects and ambush predator lizards, which facilitates the capture of this type of prey. Species of the genus Liolaemus, such as L. cuyanus CEI and SCOLARO, (1980), (Azócar and Acosta, 2011), L. pseudoanomalus BURMEISTER, (1981), (Kozykariski et al., 2011), L. bibronii (BELL, 1843) (Belver and Avila, 2001), L. wiegmannii (DUMÉRIL \& BIBRON, 1837) (Aun et al., 1999), L. koslowskyi
ETHERIDGE, 1993, (Aun and Martori, 1998), L. boulengeri KOSLOWSKY, 1898, (Acosta et al., 1996), L. darwini (BELL, 1843), (Avila and Acosta, 1993; Videla, 1983) and L. lutzae (Rocha, 1989), and lizards of the genus Tropidurus also exhibit a preference for ants (Van Sluys, 1993, 1995; Vitt and Carvalho, 1995). According to Vitt et al. (2003), Iguanid lizards consume larger proportions of ants and other Hymenoptera because these lizards occupy a different microhabitat than the Scleroglossa lizards, which consume larger proportions of termites and spiders and avoid the consumption of prey with toxic chemical defenses.

Differences between the volume of food items consumed by juveniles and adults were recorded. A positive and significant correlation between the mean size of the five largest volumes and the body size of $L$. occipitalis was observed. This species tended to consume larger prey as its body size increased. Additionally, the size of the food items was significantly correlated with the lizards' JW. This variation may be the result of morphological limitations (head size vs. jaw size) because smaller lizards can only capture smaller prey (DeMarco et al., 1985; Rocha, 1989; Van Sluys, 1993). Both body size and head size facilitate the competition for resources (Schoener, 1967, 1971) based on the decrease in intraspecific competition.

Significant differences were also observed in the quality of the items consumed by juvenile and adult lizards. Juveniles tended to consume prey with smaller amounts of chitin. Therefore, they consumed larger volumes of flies and Coleoptera larvae, whereas beetles predominated the adult diet. The ontogenetic differences in diet may be a consequence of different nutritional needs because juveniles have higher metabolic demands due to their greater growth rate compared with adults (Andrews, 1976; Stamps et al., 1981; Verrastro and Krause, 1994). Differences in the quality, size and number of consumed items in juveniles and adults were also observed in other Liolaemus species, including L. nigromaculatus, L. pictus pictus, L. lutzae and L. cuyanus (Ortiz, 1974; Ortiz and Riveros, 1976; Rocha, 1989; Azócar and Acosta, 2011).

The consumption of plant material by L. occipitalis increased positively and significantly with the individual's SVL, indicating ontogenetic variations in herbivory. This variation has been shown in several lizard species. The diet of juveniles is mostly carnivorous, but it passes through different omnivorous stages during maturation into adult life (Schoener and Gorman, 1968; Pough, 1973; Schoener et al., 1982). Several species of the genus Liolaemus (Fuentes and Di Castri, 1975; Rocha, 1989, 
1996; Acosta et al., 1996) show the same pattern. Pough (1973) attributes this observation to the larger amount of protein in a carnivorous diet. According to Szarski (1962), digesting plant material is more difficult than digesting animal material. Fuentes and Di Castri (1975) showed experimentally that three out of five Liolaemus species from Chile tend towards herbivory and that these species are present in environments with low insect abundance and marked fluctuations in the availability of these prey. Jaksic (1978) grouped the theories of Pough (1973) and Fuentes and Di Castri (1975) and proposed that the determining factor of carnivorous, omnivorous or herbivorous characteristics is the body mass - energetic cost and prey availability in the environment. Liolaemus occipitalis is another example of omnivory in small-sized lizards.

Many recent studies have demonstrated that the presence of Nematoda in the stomachs and intestines of lizards is associated with the consumption of plant material (Schad et al., 1964; Nagy et al., 1984; Iverson, 1982; Vrcibradic et al., 2000; O'Grady et al., 2005). According to O'Grady et al. (2005), the nematode parasite type and location in the digestive tract of Liolaemus lizards are highly correlated with the species' diet. Herbivorous species of this genus have a greater quantity of these parasites, which are usually found in the posterior intestine. The incidence of nematodes in omnivorous species was two times lower, and the parasites were spread throughout the intestines. Insectivorous species had four times fewer nematodes, which were usually found in the stomach (O'Grady et al., 2005). These results agree with our observation of a nematode occurrence frequency of $17 \%$ in the intestines of $L$. occipitalis. The presence of these parasites in this lizard could be associated with the consumption of plant material. This statement is supported by our observation that nematodes were more frequently found in adult $L$. occipitalis, which also consume a greater volume of plant material.

Seasonal differences in the diversity of food items consumed by L. occipitalis were observed. The diet of many lizard species varies according to the food availability in the environment (Pianka, 1970; Schoener et al., 1982; Rocha, 1996; Van Sluys, 1993, 1995), but this association should be confirmed experimentally for $L$. occipitalis. The same strategy was observed in other species of this genus, such as L. pictus pictus (DUMÉRIL \& BIBRON, 1837), (Ortiz, 1974), L. nigromaculatus WIEGMANN, 1834, (Ortiz and Riveros, 1976), L. lutzae (Rocha, 1989), L. wiegmannii (Aun et al., 1999), L. bibronii (Belver and Avila, 2001) and L. ruibali DONOSO-BARROS, 1961, (Villavicencio et al., 2005). According to Schoener (1971), Pyke et al. (1977) and Pianka and Vitt (2003), the generalist diets of most lizards are the result of environmental resource fluctuations, which is the case in the sand dunes of Cidreira (RS) because it is a region with seasonal climatic changes (Nordstrom, 2008; Würding and Freitas, 2009).

In conclusion, L. occipitalis is an omnivorous lizard that feeds on both arthropods and plant material. This species is a "sit-and-wait" forager and a generalist lizard.
The diet varied between adults and juveniles, mostly due to morphological differences, which indicates a reduction of intraspecific competition. The consumption of plant material increased with lizard size and age. Seasonal variations were observed in the diet of L. occipitalis, which is similar to the diet of other species of the same genus.

\section{Acknowledgements}

We thank our colleagues Dr. Paulo Brack and MSc. Rodrigo Caruccio for field assistance. We also thank Gustavo Scaron for reviewing the manuscript. We thank the Rio Grande do Sul State Research Foundation (Fundação de Amparo a Pesquisa do Estado do Rio Grande do Sul - FAPERGS) for the financial support.

\section{References}

ACOSTA, JC., ÁVILA, LJ. and BLANCO, G., 1996. Ecología de Liolaemus boulengeri (Sauria: Tropiduridae) en el noroeste de la estepa patagónica (Ing. Jacobacci, Río Negro, Argentina). Cuadernos de Herpetología, vol. 9, p. 100-107.

ANDREWS, RA., 1976. Growth rates in island and mainland anoline lizard. Copeia, vol. 1976, no. 3, p. 477-482. http://dx.doi. org/10.2307/1443362.

AUN, L. and MARTORI, R., 1998. Reproducción y dieta de Liolaemus koslowsky Etheridge, 1993. Cuadernos de Herpetología, vol. 12, p. 1-10.

AUN, L., MARTORI, R. and ROCHA, C., 1999. Variación estacional de la dieta de Liolaemus wiegmannii (Squamata: Tropiduridae) en un agroecossistema del Sur de Córdoba, Argentina. Cuadernos de Herpetología, vol. 13, p. 69-80.

ÁVILA, LJ, MORANDO, M., PEREZ, DR. and SITES JÚNIOR JW., 2010. A new species of the Liolaemus elongatus clade (Reptilia: Iguania: Liolaemini) from Cordillera del Viento, northwestern Patagonia, Neuquén, Argentina. Zootaxa, vol. 2667, p. 28-42.

ÁVILA, LJ. and ACOSTA, JC., 1993. Notas sobre el comportamiento de Liolaemus darwini (Sauria-Tropiduridae) en el sur de la Provincia de Mendoza. Facena, vol. 10, p. 57-61.

AZÓCAR, LM. and ACOSTA, JC., 2011. Feeding habits of Liolaemus cuyanus (Iguania: Liolaemidae) from the Monte Biogeographic Province of San Juan, Argentina. Journal of Herpetology, vol. 45, no. 3, p. 283-286. http://dx.doi.org/10.1670/10-071.1.

BELVER, LC. and ÁVILA, LJ., 2001. Diet composition of Liolaemus bibroni (Iguania: Liolaemidae) in southern Rio Negro Province, Argentina. The Herpetological Journal, vol. 12, p. 39-42.

BUJES, CS. and VERRASTRO, L., 2006. Microhabitat use by the saxicolous lizard, Liolaemus occipitalis (Squamata, Tropiduridae), in the coastal sand dunes of Rio Grande do Sul, Brazil. Iheringia, Série Zoologia, vol. 98, p. 156-160. http://dx.doi.org/10.1590/ S0073-47212008000100020.

BUJES, CS. and VERRASTRO, L., 2008. Annual activity of the lizard Liolaemus occipitalis (Squamata, Liolaemidae) in the coastal sand dunes of southern Brazil. Iheringia, Série Zoologia, vol. 98, no. 1, p. 156-160. http://dx.doi.org/10.1590/S007347212008000100020 .

COOPER, WE. Jr., 1995. Foraging mode, prey chemical discrimination, and phylogeny in lizards. Animal Behaviour, 
vol. 50 , no. 4 , p. 973-985. http://dx.doi.org/10.1016/00033472(95)80098-0.

DEMARCO, VG., DRENNER, RW. and FERGUSSON, GW., 1985. Maximum prey size of na insectivorous lizard, Sceloporus undulatus. Copeia, vol. 1985, no. 4, p. 1077-1080. http://dx.doi. org/10.2307/1445269.

DILLENBURG,LR., WAECHTER, JL. and PORTO, ML., 1992. Species composition and structure of a sandy coastal plain forest in northern Rio Grande do Sul, Brazil. In SEELIGER, U. (Ed.). Coastal Plant Communities of Latin America. New York: Academic Press. p. 349-366. http://dx.doi.org/10.1016/B978-008-092567-7.50028-3.

ESPINOZA, RE., WIENS, JJ. and TRACY, CR., 2004. Recurrent evolution of herbivory in small, cold-climate lizards: breaking the ecophysiological rules of reptilian herbivory. Evolution; International Journal of Organic Evolution, vol. 101, no. 48, p. 16819-16824. http://dx.doi.org/10.1073/pnas.0401226101. PMid:15550549

ETHERIDGE, R. and ESPINOZA, RE., 2000. Taxonomy of the Liolaeminae (Squamata: Iguania: Tropiduridae) and a semiannotated bibliography. SHIS, vol. 126, p. 1-64.

FIALHO, RF., ROCHA, CFD. and VRCIBRADIC, D., 2000. Feeding Ecology of Tropidurus torquatus: Ontogenetic Shift in Plant Consumption and Seasonal Trends in Diet. Journal of Herpetology, vol. 34, no. 2, p. 325-330. http://dx.doi.org/10.2307/1565437.

FITCH, H., 1978. Sexual size differences in the genus Sceloporus. The University of Kansas Science Bulletin, vol. 51, p. 441-461.

FUENTES, ER. and DI CASTRI, F., 1975. Ensayo experimental en especies de Liolaemus (Iguanidae) chilenos. Anales del Museo de Historia Natural de Valparaiso, vol. 8, p. 66-75.

FUENTES, ER. and IPINZA, J., 1979. A note on the diet of Liolaemus monticola (Reptilia, Lacertilia, Iguanidae). Journal of Herpetology, vol. 13, no. 1, p. 123-124. http://dx.doi.org/10.2307/1563768.

GREENE, HW.,1982. Dietary and phenotypic diversity in lizards: why are some organisms specialized? In: MOSSAKOWSKI, D. and ROTH, G. (Eds). New York: Environmental Adaptation and Evolution. p. 107-128.

HALLOY, M., ROBLES, C. and CUEZZO, F., 2006. Diet in two syntopic Neotropical lizard species of Liolaemus (Liolaemidae): interspecific and intersexual differences. Revista Española de Herpetología, vol. 20, p. 47-56.

HASENACK, H. and FERRARO, LW., 1989. Considerações sobre o clima da região de Tramandaí, RS. Pesquisas, vol. 22, p. 53-70.

HUEY, RB. and PIANKA, ER., 1981. Ecological consequences of foraging mode. Ecology, vol. 62, no. 4, p. 991-999. http:// dx.doi.org/10.2307/1936998.

INSTITUTO CHICO MENDES DE CONSERVAÇÃO DA BIODIVERSIDADE - ICMBio-MMA, 2013. Lista Nacional das Espécies da Fauna Brasileira Ameaçada de Extinção. ICMBioMMA. Available from: http://pesquisa.in.gov.br/imprensa/jsp/ visualiza/index.jsp?jornal=1\&pagina $=121 \&$ data $=18 / 12 / 2014$. Access in: 18 Dez. 2014.

IVERSON, JB.,1982. Adaptations to herbivory in iguanine lizards. In BURGHARDT, GM. and RAND, S. (Eds.). Iguanas of the world: their behavior, ecology and conservation. New Jersey: Noyes Publications. p. 60-76.

JAKSIC, FM. and FUENTES, ER., 1980. Observaciones autoecológicas en Liolaemus nitidus (Lacertilia: Iguanidae).
Studies on Neotropical Fauna and Environment, vol. 15, no. 3-4, p. 109-124. http://dx.doi.org/10.1080/01650528009360569.

JAKSIC, FM., 1978. ¿A qué tamaño se hace herbívora una lagartija? Anales del Museo de Historia Natural de Valparaíso, vol. 11, p. 113-116.

KOZYKARISKI, ML., BELVER, LC. and AVILA, LJ., 2011. Diet of the desert lizard Liolaemus pseudoanomalus (Iguania: Liolaemini) in northern La Rioja Province, Argentina. Journal of Arid Environments, vol. 75, no. 11, p. 1237-1239. http://dx.doi. org/10.1016/j.jaridenv.2011.06.004.

KREBS, CJ.,1999. Ecological methodology. 2nd ed. AddisonWesley Educational Publishers. Inc. 607 p.

LEMA, T. 1994. Lista comentada dos répteis ocorrentes no Rio Grande do Sul, Brasil. Comunicações do Museu de Ciências da PUCRS. Série Zoologia., vol. 7, p. 41-150.

MACARTHUR, RH. and PIANKA, ER., 1966. On optimal use of a patchy environment. American Naturalist, vol. 100, no. 916, p. 603-609. http://dx.doi.org/10.1086/282454.

MAGNUSSON, WE. and SILVA, EV., 1993. Relative effects of size, season and species on the diets of some Amazonian Savanna lizards. Journal of Herpetology, vol. 27, no. 4, p. 380-385. http:// dx.doi.org/10.2307/1564823.

MAGNUSSON,WE., PAIVA, LJ., ROCHA, RM., FRANKE, CR, KASPER, LA. and LIMA, AP., 1985. The correlates of foraging mode in a community of Brazilian lizards. Herpetologica, vol. 41, p. 324-332.

MAGURRAN, AE. and MCGILL, BJ., 2011. Biological diversity: frontiers in measurement and assessment. Oxford: University Press. 337 p.

MALUF, JRT., 2000. Nova classificação climática do Estado do Rio Grande do Sul. RBaGro, vol. 8, no. 1, p. 141-150.

MAYHEW, WW., 1963. Reproduction in the granite spiny lizard Sceloporus orcutti. Copeia, vol. 1963, no. 1, p. 144-152. http:// dx.doi.org/10.2307/1441282.

NAGY, KA., HUEY, RB. and BENNETT, AF., 1984. Field energetics and foraging mode of Kalahari lacertid lizards. Ecology, vol. 65 , no. 2, p. 588-596. http://dx.doi.org/10.2307/1941421.

NORDSTROM, KF.,2008. Recuperação de praias e dunas. São Paulo: Editora Oficina de Textos. 263 p.

O'GRADY, SP., MORANDO, M., AVILA, L. and DEARING, MD., and the O'GRADY, 2005. Correlating diet and digestive tract specialization: examples from the lizard family Liolaemidae. Zoology (Jena, Germany), vol. 108, no. 3, p. 201-210. http://dx.doi. org/10.1016/j.zool.2005.06.002. PMid:16351968

ORTIZ, JC. and RIVEROS, GM., 1976. Habitos alimentícios de Liolaemus nigromaculata kuhlmani, Muller and Hellmich. Anales del Museo de Historia Natural de Valparaiso, vol. 9, p. 131-140.

ORTIZ, JC., 1974. Reptiles del Parque Nacional "Vicente Perez Rosales". I. Hábitos alimentícios em Liolaemus pictus pictus. Anales del Museo de Historia Natural de Valparaiso, vol. 7, p. 317-326.

PETERS, JA., OREJAS-MIRANDA, B. and VANZOLINI, PE., 1986. Catalogue of the Neotropical Squamata (Revised Edition). Part II - Lizards and Amphisbaenians. Washington, Smithsonian Institution Press. VIII +293 p.

PIANKA, ER. and VITT, LJ., 2003. Lizards: windows to the evolution of diversity. London: University of California Press. 333 p. 
PIANKA, ER., 1970. Comparative autoecology of the lizard Cnemidophorus tigris in different part of its geographic range. Ecology, vol. 51, no. 4, p. 703-720. http://dx.doi.org/10.2307/1934053.

PIANKA, ER., 1982. Ecologia evolutiva. Barcelona: Editora Omega. $365 \mathrm{p}$.

POUGH, FH., 1973. Lizard energetic and diet. Ecology, vol. 54, no. 4, p. 837-844. http://dx.doi.org/10.2307/1935678

PYKE, GH., PULLIAM, HR. and CHARNOV, EL., 1977. Optimal foraging: a selective review of theory and test. The Quarterly Review of Biology, vol. 52, no. 2, p. 137-154. http:// dx.doi.org/10.1086/409852.

ROCHA, CFD., 1989. Diet of a tropical lizard (Liolaemus lutzae) of southeastern Brazil. Journal of Herpetology, vol. 23, no. 3, p. 292-294. http://dx.doi.org/10.2307/1564451.

ROCHA, CFD., 1992. Ecologia e comportamento de Liolaemus lutzae (Sauria: Tropiduridae) em uma área de restinga do sudeste do Brasil. Campinas: Universidade Estadual de Campinas. 176 p. Tese de Doutorado.

ROCHA, CFD., 1996. Seasonal shift in lizard diet: the seasonality in food resources affecting the diet of Liolaemus lutzae (Tropiduridae). Ciencia e Cultura, vol. 4, no. 48, p. 264-269.

SCHAD, GA., KNOWLES, R. and MEEROVITCH, E., 1964. The occurrence of Lampropedia in the intestines of some reptiles and nematodes. Canadian Journal of Microbiology, vol. 10, no. 5, p. 801-804. http://dx.doi.org/10.1139/m64-101. PMid:14222662

SCHOENER, TW. and GORMAN, GC., 1968. Some niche differences in three Lesser Antillean lizards of the genus Anolis. Ecology, vol. 49, no. 5, p. 819-830. http://dx.doi.org/10.2307/1936533.

SCHOENER, TW., 1967. The ecological significance of sexual dimorphism in size in the lizard Anolis conspersus. Science, vol. 155, no. 3761, p. 474-477. http://dx.doi.org/10.1126/ science.155.3761.474. PMid:17737565

SCHOENER, TW., 1971. Theory of feeding strategies. Annual Review of Ecology Evolution and Systematics, vol. 2, no. 1, p. 369-404. http://dx.doi.org/10.1146/annurev.es.02.110171.002101.

SCHOENER, TW., SLADE, JB. and STINSON, CH., 1982. Diet and sexual dimorphism in the very catholic lizard genus Leiocephalus of the Bahamas. Oecologia, vol. 53, no. 2, p. 160169. http://dx.doi.org/10.1007/BF00545659.

SIEGEL, S., 1975. Estatística não paramétrica para as ciências do comportamento. Rio de Janeiro: McGraw-Hill. 350 p.

SILVA, V. and ARAÚJO, AFB., 2008. Ecologia dos lagartos brasileiros. Rio de Janeiro: Redb Style Produções Gráficas e Editorial Ltda. $256 \mathrm{p}$

STAMPS, J., TANAKA, S. and KRISHNAN, VV., 1981. The relationship between selectivity and food abundance in a juvenile lizard. Ecology, vol. 62, no. 4, p. 1079-1092. http://dx.doi. org/10.2307/1937006

STEPHEN, MR., MCBRAYER, LB. and DONALD, BM., 2007. Lizard Ecology. New York: Cambridge University Press. 541 p.

SZARSKI, H., 1962. Some remarks on herbivorous lizards. Evolution; International Journal of Organic Evolution, vol. 16, no. 4, p. 529. http://dx.doi.org/10.2307/2406186.

TEIXEIRA-FILHO, PF., ROCHA, CF. and RIBAS, SC., and the TEIXEIRA, 2003. Relative feeding specialization may depress ontogenetic, seasonal, and sexual variations in diet: the endemic lizard Cnemidophorus littoralis (Teiidae). Brazilian Journal of Biology, vol. 63, no. 2, p. 321-328. http://dx.doi.org/10.1590/ S1519-69842003000200017. PMid:14509854

TULLI, MJ., ABDALA, V. and CRUZ, FB., 2011. Relationships among morphology, clinging performance and habitat use in Liolaemini lizards. Journal of Evolutionary Biology, vol. 24, no. 4, p. 843-855. http://dx.doi.org/10.1111/j.1420-9101.2010.02218.x.

VAN SLUYS, M., 1993. Food habitats of the lizard Tropidurus itambere (Tropiduridae) in Southeasten Brazil. Journal of Herpetology, vol. 27, no. 3, p. 347-351. http://dx.doi.org/10.2307/1565162.

VAN SLUYS, M., 1995. Seasonal variation in prey choice by the lizard Tropidurus itambere (Tropiduridae) in southeastern Brazil. Ciencia e Cultura, vol. 47, no. v2, p. 61-65.

VEGA, LE., 1999. Ecología trófica de Liolaemus multimaculatus (Sauria:Tropiduridae). Bolletino del Museo Regionale di Scienze Naturali di Torino, vol. 16, p. 27-38

VERRASTRO, L. and BUJES, CS., 1998. Ritmo de atividade de Liolaemus occipitalis Boulenger, 1885 (Sauria, Tropiduridae) na praia de Quintão, RS - Brasil. Revista Brasileira de Zoologia, vol. 15 , no. 4 , p. $907-914$

VERRASTRO, L. and KRAUSE, L., 1994. Analysis of growth in a population of Liolaemus occipitalis Boul. 1885, from the coastal sand-dunes of Tramandai, RS, Brazil (Reptilia, Tropiduridae). Studies on Neotropical Fauna and Environment, vol. 29, no. 2, p. 99-111. http://dx.doi.org/10.1080/01650529409360922.

VERRASTRO, L. and KRAUSE, L., 1999. Ciclo reprodutor de machos em Liolaemus occipitalis Boulenger, 1885. (SauriaTropiduridae). Revista Brasileira de Zoologia, vol. 16, no. 1, p. 227-231. http://dx.doi.org/10.1590/S0101-81751999000100019.

VERRASTRO, L., 2001. Descrição, estratégia reprodutiva e alimentar de uma nova espécie do gênero Liolaemus no Estado do Rio Grande do sul, Brasil. (Iguania: Tropiduridae). São Carlos: Universidade Federal de São Carlos. 315 p Tese de Doutorado em Ecologia e Recursos Naturais Renováveis.

VERRASTRO, L., 2004. Sexual dimorphism in Liolaemus occipitalis (Iguania, Tropiduridae). Iheringia. Série Zoologia, vol. 94, no. 1, p. 45-48. http://dx.doi.org/10.1590/S0073-47212004000100007.

VERRASTRO, L., SCHOSSLER, M. and SILVA, CM., 2006. Liolaemus occipitalis. Herpetological Review, vol. 37, p. 495.

VIDELA, F., 1983. Hábitos alimentarios en iguánidos del oeste árido de la Argentina. Deserta, vol. 7, p. 192-202.

VILLAVICENCIO, HJ., ACOSTA, JC. and CÁNOVAS, MG., 2005. Dieta de Liolaemus ruibali Donoso Barros (Iguania: Liolaeminae) en la Reserva de Usos Múltiples Don Carmelo. Multequina, vol. 14, p. 47-52

VITT, LJ. and CALDWELL, JP., 2009. Herpetology: an introductory biology of amphibians and reptiles. 3rd ed. Oxford: Academic Press. 697 p.

VITT, LJ. and CARVALHO, CM., 1995. Niche partitioning in a tropical wet season: lizards in the lavrado area of northern Brazil. Copeia, vol. 1995, no. 2, p. 305-329. http://dx.doi. org/10.2307/1446894.

VITT, LJ. and LACHER, JTE., 1981. Behavior, habitat, diet, and reproduction of the iguanid lizard Polychrus acutirostris in the caatinga of northeastern Brazil. Herpetologica, vol. 37, no. 1, p. 53-63. 
VITT, LJ., 1990. The influence of foraging mode and phylogeny on seasonality of tropical lizard reproduction. Papéis Avulsos de Zoologia, vol. 37, no. 6, p. 107-123.

VITT, LJ., 1991. Ecology and life-history of the widely foraging lizard Kentropyx calcarata (Teiidae) in Amazonian Brazil. Canadian Journal of Zoology, vol. 69, no. 11, p. 2791-2799. http://dx.doi. org/10.1139/z91-393.

VITT, LJ., PIANKA, ER., COOPER, WE Jr. and SCHWENK, K., 2003. History and the global ecology of squamate reptiles. American Naturalist, vol. 162, no. 1, p. 44-60. http://dx.doi. org/10.1086/375172. PMid:12856236

VRCIBRADIC, D. and ROCHA, CFD., 1995. Variação sazonal na dieta de Mabuya macrorhincha (Sauria- Scincidae) na restinga da Barra de Maricá, RJ. Oecologia Brasiliensis, vol. 1, no. 01, p. 143-153. http://dx.doi.org/10.4257/oeco.1995.0101.05.
VRCIBRADIC, D., CUNHA-BARROS, M., VICENTE, JJ., CONRADO, ACG., HATANO, FH., VAN SLUYS, M. and ROCHA, CFD., 2000. Nematode infection patterns in four sympatric lizards from a restinga habitat (Jurubatiba) in Rio de Janeiro state, southeastern Brazil. Amphibia-Reptilia, vol. 21, no. 3, p. 307-316. http://dx.doi.org/10.1163/156853800507507.

WAECHTER, JL., 1990. Comunidades vegetais das restingas do RS. In Anais do II Simpósio de Ecossitemas da Costa Sudeste Brasileira, 1990. Águas de Lindóia. Águas de Lindóia: ACIESP. vol. 3 , p. $228-248$.

WÜRDING, L. and FREITAS, SMF., 2009. Ecossistemas e biodiversidade do Litoral Norte do Rio Grande do Sul. 1st ed. Porto Alegre: Nova Prova. 287 p.

ZAR, JH., 1984. Biostatistical analysis. Englewood Cliffs: Prentice-Hall Inc. 718 p. 